\title{
MASCULINIZATION AND EFFECT OF NILE TILAPIA Oreochromisniloticus FED WITH PAWPAW SEED BASED DIET AND STEROID HORMONE
}

\author{
Orose, E.Wokeh, O.K \\ Department Of Animal And Environmental Biology, Faculty Of Science, \\ University Of Port Harcourt, Rivers State, Nigeria
}

\begin{abstract}
This study was conducted to assess the effect of 17a- methyl-testosterone, wet testes of boar (Sus. domesticus) and pawpaw seed powder based diet (Carica papaya) on masculinization of Nile tilapia fry in an indoor experimental ponds. The efficacies in producing monosex males were determined after 4months. Fifty five fry were assigned randomly to five experimental ponds in triplicate. The feed composed of soya-bean, fish meal, wheat bran, cassava flour in Pond A1, $\mathrm{A2}, \mathrm{A3}, \mathrm{A} 4$ and $\mathrm{A5}$ were formulated by adding $0.06 \mathrm{~g}$ of $17 \alpha$ - methyl-testosterone (A1) $17.47 \mathrm{~g}$ of bull wet testes (A2) $25.59 \mathrm{~g}$ of boar wet testes (A3), 20.48g of bull/African mud catfish (A4) at (80:20), and (A5) $20 \mathrm{~g}$ of pawpaw seed powder respectively per $\mathrm{kg}$ of feed. Results from the morphological examination revealed significant different $(p<0.05)$ in phenotypic males of Nile tilapia fry fed with the highest percent in MT-treated diet (A1) of $100 \pm 0.00^{\mathrm{a}}$ while $\mathrm{A2}$ and $\mathrm{A3}$ had males of $93.40 \pm 0.76{ }^{b} \quad 78.48 \pm 2.40^{d}$ respectively. The phytochemical constituent found in the experimental pawpaw seed powder showed that it contain Cyanogenic glycoside of $\mathbf{0 . 0 4 2 \%}$ which was the lowest constituent followed by Tannin 9.23\% having the highest constituent. Therefore, natural product can be an alternative method to produce all-male tilapia population in an environment-friendly manner
\end{abstract}

Keywords: Oreochromis niloticus, monosex, 17 $\alpha$ methyl-testosterone, organic farming.

\section{INTRODUCTION}

Nile Tilapia (Oreochromis niloticus) is one of the most commonly cultured freshwater fish species in
Nigeria. It is a prolific breeder, widely farmed across the nations of the earth and the third largest cultured finfish [1]. Oreochromis niloticus is a native of Africa [2], considered as a standout farmed fish because of its high nutritional qualities, fast growth rate, resistance to diseases and its ability to withstand sudden environmental changes [3]. In spite of these enviable characteristics, one major setback on commercial production of tilapia is the prolific breeding nature as well as its precocious maturity which brings about competition for space, feed, stunted growth and low market value [4]. As a result, there is a huge apathy amongst aquaculturist to culture Nile tilapia for commercial purposes. In order to proffer solution to this problem, it is important to masculinize(all male)populations of tilapia(Oreochromis niloticus) present in a pond, to inhibit the tendency of overpopulating the ponds, thereby allowing the production of marketable sized fish, which is the most effective technique of increasing Nile tilapia production under commercial culture system [5]. This could be achieved by the use of 17alpha methyl testeresterone, viewed my many aquaculturist as efficient and relatively a cheap means of masculinizing fry of at least 95percent for various tilapia species[6](Pelps and Popma 2000). Unfortunately, the use of this hormone has been widely criticized due to the negative effects of its residues in water and sediment, as well as the health implications to man [7].Therefore, there is urgent need to source for alternatives that are cheap, non-toxic and readily available.

The alternatives that can be considered to reduce the use of synthetic steroid hormone for sex reversal of tilapia is the use of testes from farmed animals and plant extract (pawpaw seed powder) which are available from local market and abattoirs in the country. Little literature is available in the use of 


\section{International Journal of Engineering Applied Sciences and Technology, 2020 \\ Vol. 5, Issue 5, ISSN No. 2455-2143, Pages 291-297 \\ Published Online September 2020 in IJEAST (http://www.ijeast.com)}

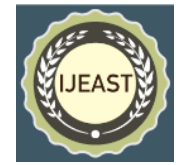

hormone from animals and plant extract, there is therefore need to add to the existing knowledge in this area of interest which has been given less attention in this nation. Plant sources with potential reversing mechanism and growth-promoting effects could be worth studying since they have not been subjected to licensing for use in food animals. Many researchers used pawpaw seeds powder (PSP) as a natural reproductive inhibitor in Nile tilapia [8]. On the other hand, some of results showed that adding of PSP in diets caused delay of growth and high percentage of mortality in Nile tilapia fry $[9,10$ and 8]. Therefore, the present study was conducted to determine the effects of dietary supplementation of pawpaw seeds powder (PSP) based diet and methyl testosterone on hormonal imbalance of Nile tilapia (Oreochromis niloticus) fry and fingerlings.

\section{MATERIALS AND METHODS}

A total of (825) fry of Oreochromisniloticus (Nile tilapia) were obtained from the Tilapia family testing unit of Africa Regional Aquacultural Center (ARAC) Aluu, Port Harcout, Rivers State. The experiment was carried out in 15 different experimental ponds at ARAC and was distributed randomly into five groups, with Fifty five (55) fry each in triplicate. Steroid hormone ( $17 \alpha$ - methyl-testosterone)was gotten from the University of Lagos, Lagos State, boar testes was procured from Abuloma abattoir in Port Harcourt, while pawpaw fruit was collected from the Faculty of Agriculture experimental farm University of Port Harcourt and was sun-dried, grind.

\section{Hormone preparation}

$60 \mathrm{mg}$ of $17 \alpha$-Methyl testosterone and $10 \mathrm{~g}$ of boar and bull testes, $4 \mathrm{~g}$ of catfish testes were placed in a beaker containing $500 \mathrm{ml}$ of ethanol $(95 \%)$ respectively, while $5.7 \mathrm{~g}$ of pawpaw seed powder were dissolved in water for hormonal analysis (testosterone/estrogen) at the Chemical Pathology Laboratory, University of Port Harcourt Teaching Hospital (UPTH) for hormonal analysis. Total testosterones from serum of each experimental animal were analyzed using Enzyme Immunoassay Testosterone test kit). The formulated feed was prepared by adding $0.06 \mathrm{~g}$ of $17 \alpha$ - methyl-testosterone (A1), 17.47g of bull wet testes (A2), 25.59g of boar wet testes (A3), 20.48g of bull/African mud catfish
(A4) at (80:20) 20.48g, and 20g of pawpaw seed powder (A5) based diet respectively to $1000 \mathrm{~g}$ of feed as described by [11].

\section{Exposure of test organisms:}

Two kilogram of feed was formulated based on the working composition obtained from the feed mill of ARAC, using $40 \%$ crude protein. The feed ingredients were composed of soya-bean, fish meal, wheat bran in various percentages as describe by [12]. The feeding frequency was three times daily during daylight. Feeding was given at $20 \%$ of fish body weight for 42days hormonal trial. Thereafter, the fry were reared for 4months for histology.

\section{Qualitative phytochemical analysis of pawpaw seed powder \\ Qualitative phytochemical analysis of the pawpaw seed powder was carried out using standard procedures as described by [13].}

\section{Sex determination:}

The sex of fingerlings was determined at the end of 4 months rearing period. Fingerlings in each treatment were collected in all the replicates and sex was confirmed by examining the external genitals of their gonads.

\section{Data Analysis}

Results were analyzed using Statistical Package for Social Sciences (SPSS) version 21. The data were expressed using descriptive statistical and percentages. Data gathered were subjected to Analysis of Variance (ANOVA) to determine significant differences among treatments. P-value less than or equal to 0.05 were taken as statistically significant. Differences were regarded as significant at $\mathrm{P}<0.05$. Duncan multiply range test (DMRT) was used to compare the means of significant result.

\section{RESULTS}

\section{Monthly final weight gain}

The final mean weights for all groups were significantly different $(\mathrm{p}<0.05)$ (Fig 1). Group A1 (Control) recorded the least mean final weight followed by group A2, A4, and A5 the highest was recorded in group $\mathrm{A} 3$. 


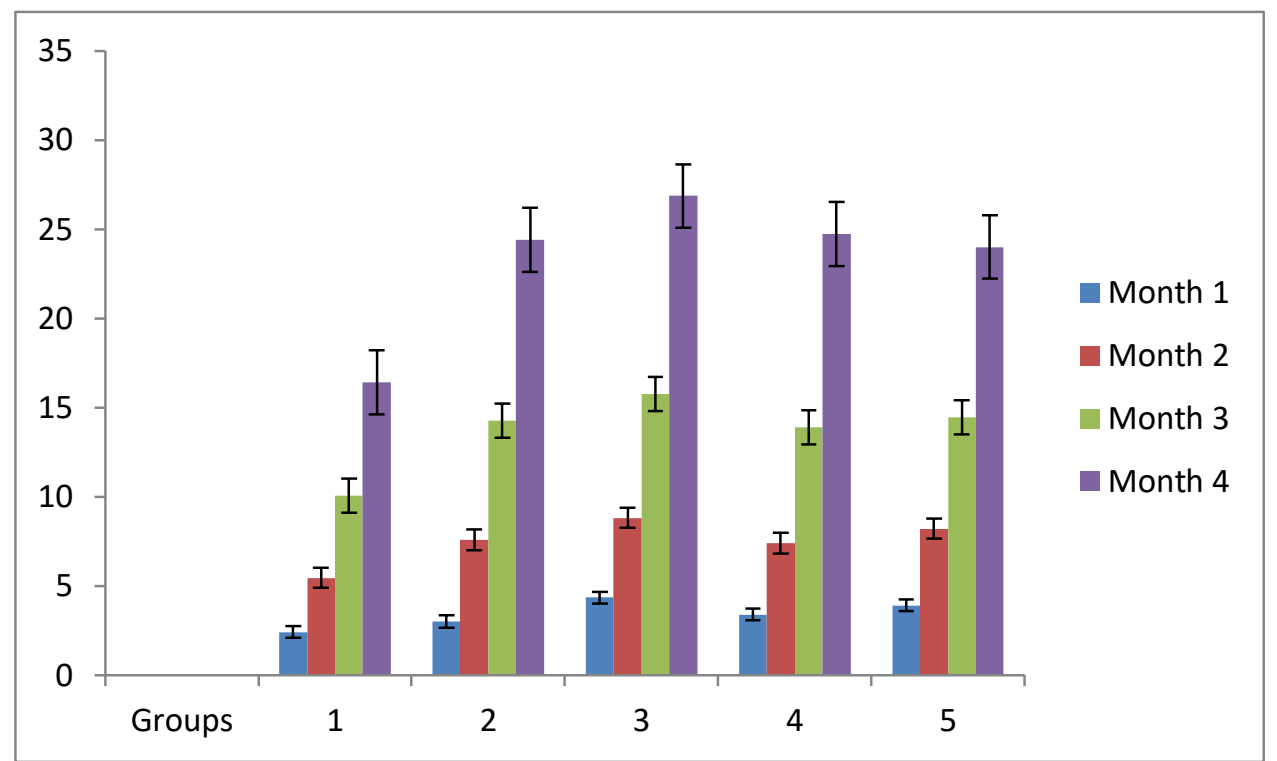

Figure 1: Monthly final weight of Nile tilapia (Oreochromis niloticus) during the experimental trial

\section{Effect of experimental diet on Masculinization of Nile Tilapia (O. niloticus)}

Morphological examination on sex ratio is presented in Table 1. MT- treated based diet (Control) had the highest male population (100\%). The least male value was observed in Group E (78.48 $\pm 2.04 \%)$ Table1. MT based diet recorded the highest male/female ratio which was significantly different $(\mathrm{p}<0.05)$ from other treatment.

Table 1: Morphological effect of Treatments on sex ratio of $O$. niloticus

\begin{tabular}{llllll}
\hline PARAMETERS & \multicolumn{5}{c}{ TREATMENTS } \\
\hline & A1 & A2 & A3 & A4 & A5 \\
\hline No observed & 58 & 101 & 121 & 109 & 113 \\
Male & $19.00 \pm 1.53^{\mathrm{c}}$ & $30.00 \pm 2.00^{\mathrm{b}}$ & $37.67 \pm 1.20^{\mathrm{a}}$ & $36.67 \pm 0.88^{\mathrm{a}}$ & $30.33 \pm 0.88^{\mathrm{b}}$ \\
Female & $0.00 \pm 0.00^{\mathrm{d}}$ & $3.67 \pm 0.33^{\mathrm{b}}$ & $2.67 \pm 0.33^{\mathrm{c}}$ & $3.00 \pm 0.00^{\mathrm{bc}}$ & $7.33 \pm 0.33^{\mathrm{a}}$ \\
\%Male & $100 \pm 0.00^{\mathrm{a}}$ & $89.14 \pm 0.25^{\mathrm{c}}$ & $93.40 \pm 0.76^{\mathrm{b}}$ & $92.43 \pm 0.17^{\mathrm{b}}$ & $78.48 \pm 2.40^{\mathrm{d}}$ \\
\%Female & $0.00 \pm 0.00^{\mathrm{c}}$ & $11.78 \pm 1.08^{\mathrm{b}}$ & $8.31 \pm 0.99^{\mathrm{b}}$ & $8.36 \pm 0.95^{\mathrm{a}}$ & $20.40 \pm 1.98^{\mathrm{a}}$ \\
\hline
\end{tabular}

\section{Phytochemical constituents of pawpaw seed powder (Carica Papaya)}

The phytochemical constituent found in the experimental pawpaw seed powder showed that it contain Cyanogenic glycoside of $0.042 \%$ which was the lowest constituent followed by Saponin $1.28 \%$, Alkaloid $2.31 \%$, flavonoid 2.97\%, Anthraquinol $5.11 \%$ and Tannin $9.23 \%$ having the highest constituent (Table 2).

Table 2: Photochemical constituents of ripe pawpaw seed powder (Carica Papaya)

\begin{tabular}{ll}
\hline PHYTOCHEMICALS CONSTITUENTS $(\%)$ & EXTRACTS \\
\hline Cyanogenic glycoside & 0.042 \\
Alkaloid & 2.31 \\
Flavonoid & 2.97 \\
Saponin & 1.28 \\
Anthraquinol & 5.11 \\
Tanin & 9.23 \\
\hline
\end{tabular}

Influence of experimental diets on gonad development 


\section{International Journal of Engineering Applied Sciences and Technology, 2020 \\ Vol. 5, Issue 5, ISSN No. 2455-2143, Pages 291-297 \\ Published Online September 2020 in IJEAST (http://www.ijeast.com)}

The presents figure represent the resulting degree of gonad differentiation observed and recorded for sexually mature tilapia that received various experimental diets. Figure1 and 2 represent a comparison of normal and abnormal gonad differentiation observed in sexually tilapia that received various experimental diets over a period of 4months

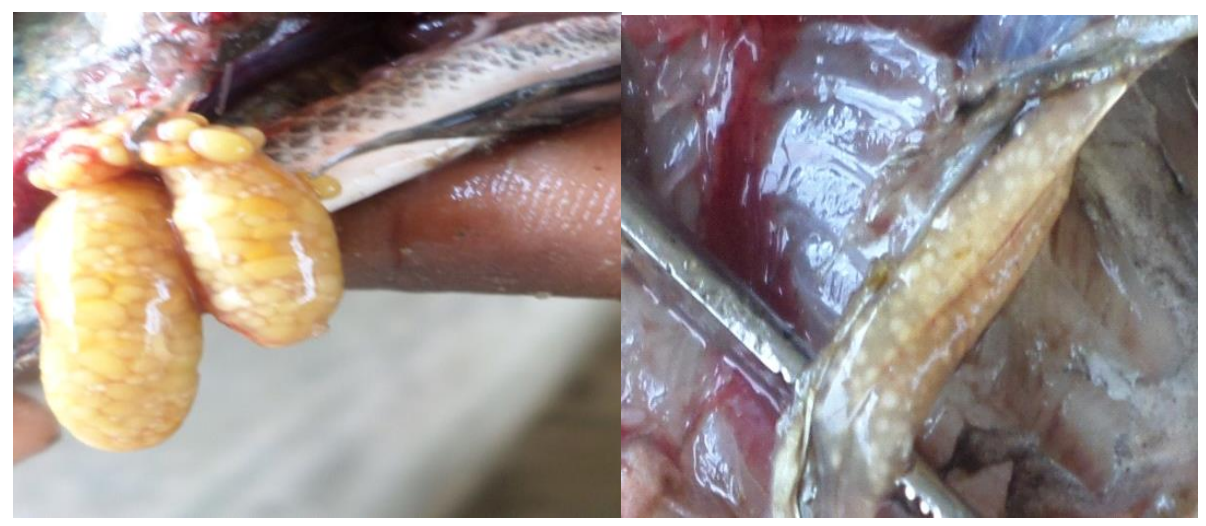

Figure 1: enlarged ovaries

Figure 2: abnormal ovaries

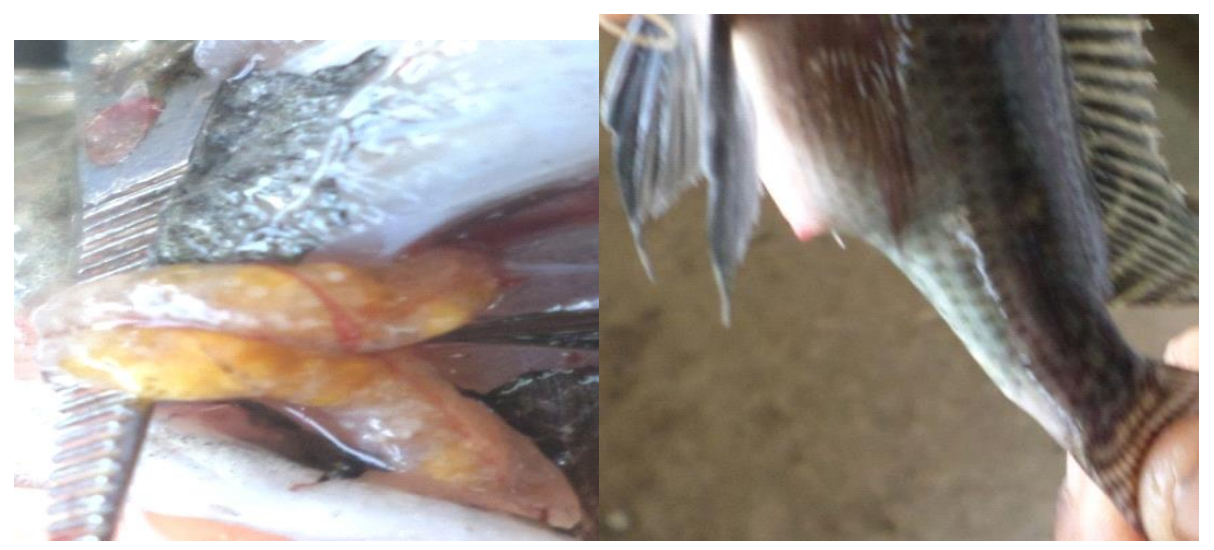

Figure 3: deformed eggs

Figure 4: Abnormal growth

\section{DISCUSSION}

The morphological external examination on the gonad (genital papillae) of $O$. niloticus showed little variation from the gonad examination. The result on the gonad examination of Groups A1 -A5 (100, 89.14, 93.40, 92.43 and 78.48) on $O$. niloticusis shown in Table 1. The result showed that there where significance difference within the means of Treatments. O. niloticus fed the control diet (Group AI) obtained the highest percentage male population. The result obtained is in line with the findings of [14, 15] who reported $100 \%$ reversal but disagrees with the findings of [16, 17 and 18]. However other treatment groups were able to skewed sex to male deviating from the theoretical 50:50 sex ratio. Group A3 had male ratio of 93.40 this findings disagrees with [19] who had $79.33 \%$ male ratio when fed lypolized boar testes diet. Gomelsky et al. [20] and Odin et al. [21] reported that hormones administered for sex reversal are metabolized and eliminated from the body of fish. Abucay and Mair [22] observed sex reversal of untreated fish reared within a system previously used with hormone treatment. He also reported that sex reversal treatments are more successful in closed water systems where metabolites and leachates can build up. In this study, the active metabolites of the testosterone excreted by treated fry during sex reversal from the uneaten food increase the build-up of the hormone during the treatment period. The longer exposure of the treated fry to active metabolites of testosterone may have increase the percentages of males produced in this study. However, these results are higher compared to the reported $74 \%$ male population of sex-reversed tilapia fry fed with carp testes for 24 days by [23]. Meyer et 


\section{International Journal of Engineering Applied Sciences and Technology, 2020 \\ Vol. 5, Issue 5, ISSN No. 2455-2143, Pages 291-297 \\ Published Online September 2020 in IJEAST (http://www.ijeast.com)}

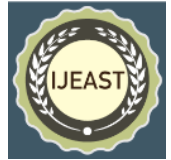

al. [24] where percent males obtained from tilapia fry fed ad libitum with fresh bull testes and fresh hog testes were 87 and $83 \%$, respectively and lower compare to the reported $93 \%$ phenotypic males produced from ad libitum feeding of tilapia fry with frozen bull testes after 30-day treatment period [25].

Similarly, [19] concluded that the process of lyophilization of the testes from animal might have reduced their efficiency. This shows that the age and size of fish fry is a function of environmental factors which also influences the growth and gonad differentiation of fish species [6]. However failure to obtained $100 \%$ male ratio using animal testes might be that during animal testes diet preparation, the tough and fibrous septa inside the testes were not removed and the indigestible parts of the testes remained in the diet. In this study, it is assumed that the fry treated with the animal testes diet assimilated less amount of testosterone since some parts of the diet were indigestible in the fish body. The low percentages of males obtained from tilapia fry fed with wet testes from bull, boar and a combination of bull and mud catfish might be attributed to the restricted feeding of tilapia fry with testes diets at $20 \%$ feeding rate in this study, the duration of the experiment and increase in growth rate compare to MT diet. Hence, it is assumed that fry which were masculinized consumed fewer hormones than the required minimum amount for sex reversal during the gonad differentiation period.

Meanwhile, plant extract (pawpaw seed powder) showed the least percentage $73 \%$ in this study. This might be as a result of high estrogen found in PSP as against testosterone concentration. Omeje et al., [26] reported that pawpaw seed extract had masculinizing effect on fish but inclusion level varied their efficacy. This assertion was in line with the findings of [27] who reported $65 \%$ male population at $15 \mathrm{~g} / \mathrm{kg}$ inclusion level. The male ratio in this study might be as a result of the phytochemical constituents (table 2) found in PSP.

\section{CONCLUSION}

It can be concluded that steroid, animal hormone and pawpaw seed based diet showed efficacy of mansculization although pawpaw seed powder have the capacity to delay puberty, and restrain the precocious breeding in tilapias, thus could be used successfully to control reproduction in tilapia. However, the highest percentage of males produced by pawpaw seed based diet is $78 \%$, which is below the ideal requirement of $100 \%$ male population. An ideal treatment would be required for the production of all-male tilapia population using steroid, animal hormone and plant extract to establish a conclusive evidence regarding its efficacy to be used as a sex-reversal agent in tilapia culture, on the appropriate inclusion levels and duration of application, size of the fish for commercial purpose.

\section{ACKNOWLEDGEMENT}

I wish to express my sincere thanks to staff of African Regional Aquaculture Center (ARAC) for their approval and support to conduct this research at their center.

\section{REFERENCES}

[1] Ogola M., Owiti, D. O., and Ominde, J. (2020): Growth performance of Nile tilapia(Oreochromis niloticus) fingerlings fed on Soybean (Glycine max) compared to dagaa (Rastrineobola argentea) meal with diet supplement of maize bran. Journal of fisheries Research, 4(1):14-20

[2] Deines, A. M., Bbole, I., Katongo, C., Feder, J. L., and Lodge, D. M. (2014). Hybridisation between native Oreochromis species and introduced Nile tilapia O. niloticus in the Kafue River, Zambia. African Journal of Aquatic Science, 39: (1), 23-34.

[3] Nakkina, M., (2016): Study of Growth Rate in Nile Tilapia (Oreochromis niloticus). Journal of Aquaculture Research \& Development, 7(8):1-4

[4] Omar, E. A., Yousef M. I., Srour, T. M ., and Mansour A. T. E. (2014): Effect of dietary natural phytochemicals on sex-reversal, growth performance, feed utilization and body composition of Nile tilapia (Oreochromis niloticus) fry. Spanish Journal of Agricultural Research, 19(3):428-440

[5] Alcantar-Vazquez, J. P., (2018): Sex proportion in Nile tilapia Oreochromis niloticus fed estrogen mixture:a case of paradoxical masculinization. Latin American Journal of aquatic research, 46(2):337-345

[6] Phelps, R. P., and Popma, T. J. (2000).Sex Reversal of Tilapia.In: Costa-Pierce, B.A. and Rakocy, J. E. (eds). Tilapia Aquaculture in the Americas 2. The World Aquaculture Society, Baton Rouge, Louisiana, United States, 2:34-59.

[7] Dias-Neto, J., Valladao, G.M.R., Viadanna, P.H.O., and Pilarski, F. (2016):Three 


\section{International Journal of Engineering Applied Sciences and Technology, 2020 \\ Vol. 5, Issue 5, ISSN No. 2455-2143, Pages 291-297 \\ Published Online September 2020 in IJEAST (http://www.ijeast.com)}

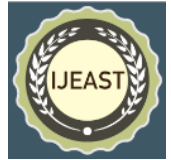

strategic feeding during hatchering of Nile tilapia:effects on organ integrity, parasitism and performance parameters. Int. Aquat Res, 8: $37-48$

[8] Abbas, H. H., and Abbas, W. T. (2011) Assessment studies on the use of Pawpaw; Carica papaya seeds to control Oreochromis niloticus breeding. Pakistan Journal of Biological Sciences, 14: 11171123.

[9] Ekanem, S. B., and Okoronkwo, T. E. (2003). Pawpaw seed as a fertility control agent on male Nile tilapia. NAGA, World Fish Center Quarterly, 26 (2): 8-10.

[10] Ayotunde, E. O., and Ofem, B. O. (2008). Acute and chronic toxicity of pawpaw (Carica papaya) powder to Nile tilapia Oreochromis niloticus (Linne 1757), fingerlings. African Jorunal of Biotechnol., 7 (13): 2265-2274.

[11] Orose, E.; Woke; G. N., and Bekibele, D.O (2018). Growth Response and Survival of Nile Tilapia (Oreochromis niloticus) using Steroid Hormone, Animal Testes and Pawpaw Seed based diet . Nigerian Journal of Fisheries, 15(1): 1336-1341.

[12] Orose, E., and Vincent-Akpu, I.F. (2016). CostBenefit on Masculination of Nile Tilapia (Oreochromis niloticus) using Natural and Artificial Hormone. International Journal of Biosciences and Technology, 9(8), 46

[13] Ray, S., Chatterjee, S., and Chakrabarti, C.S., (2013). Antiprolifertive activity of allelochemicalspresent in aqueous extract of Synedrellanodiflora(L.) Gaertn.in apical meristems and Wistar rat bone marrow cells. IOSR Journal of Pharmacy, 3 (2): 1-10

[14] Anocha, K., (2014) Efficacy of Red KwaoKrua (Butea superb Roxb.) crude extract for all male production of Nile tilapia (Oreochromis niloticus). Journal of Agricultural Technology 10(2):391-398

[15] Adel, M. E. S., Ashraf, A., Ramadan, A., and Khattab, A. E. (2006). Sex reversal of Nile tilapia fry using different doses of 17 amethyl testosterone at different dietary protein levels.Central Laboratory for Aquaculture Research, Abbassa, AboHammad, Sharkia Governorate, Egypt.1$12 .$.

[16]Celik, I., Guner, Y., and Celik, P., (2011).Effect of orally-administered 17 methyltestosterone at different doses on the sex reversal of the Nile tilapia (Oreochromis niloticus, Linneaus
1758).Jorunal of AniminalVeternairy Advancement, 10 (7): 853-857.

[17] Nani, G. D., Ferdous, A. L. M., Prabal, B., Abdullah, A. M. S. and Shah, M. N. C., (2010). Survivality of Mono- Sex Tilapia (Oreochromis niloticus) Fry Using 17- $\alpha$ science and nutrition (2): 16-24.

[18] Ferdous, Z., Nahar, N., Hossen, M. S., Sumi, K. R., \& Ali, M. M. (2014). Performance of different feeding frequency on growth indices and survival of monosex tilapia, Oreochromis niloticus (Teleostei: Cichlidae) fry. Int J Fish Aquat Stud, 1(5), 80-83.

[19] Odin, R. Y., and Boliva, R. B., (2011).Masculinization of Nile tilapia (Oreochromis niloticus L.) using testes from carabao (Bubalus bubalis L.), cattle (Bostaurus L.), and Hog (Sus domesticus In Better science, better fish, better life. Proceedings of the Ninth International Symposium on Tilapia in Aquaculture, Shanghai, China, 22-24 April 2011, pg 105120.

[20]Gomelsky, B., Cherfas, N.B., Peretz, Y., BenDom, N. and Hulata, G. (1994).Hormonal sex inversion in the common carp (Cyprinus carpio L.)Aquaculture, 126:265-270.

[21] Odin, R. Y., Germino, L. S., Noscal, L. D., Sugue, J. R. A., Argueza, R. L. B., \& Abella, T. A. (2009). Masculinization of Nile tilapia (Oreochromis niloticus L.) using testes from carabao (Bubalus bubalis L.), cattle (Bos taurus L.), and Hog (Sus domesticus E.). In Book of Abstracts 29th Annual PAASE Meeting and Symposium Linking Science and Engineering to Development. The Philippine-American Academy of Science and Engineering (PAASE). Quezon City, Philippines (p. 151)

[22] Abucay, J. S., and Mair, G .C.,(1997). Hormonal sex reversal of tilapias: implications of hormone treatment application in closed water systems. Aquaculture Research, 28: 841-845.

[23] Khanal, N. B., Shrestha, M. K., Rai, S. and Bhujel, R. C. (2015). Comparative evaluation of Carp testis as an alternative to $17 \alpha$-Methyltestosterone on Tilapia sex reversal. Our Nature, 12(1): 1-7.

[24] Meyer, D., Guevara, M., Chan, W. and Castillo, C., (2008). Use of fresh bull and hog testis in the reversal of Nile tilapia fry. Paper presented at the World Aquaculture 2008, The Annual International Conference and Exposition of World Aquaculture Society 
and Korean Aquaculture Society. Busan, Korea. Page 1-26.

[25] White, E. M., (2008). Evaluación del testículo de torocomofuente de testosterona en la reversion sexual dealevines de tilapia Oreochromis niloticus en agua con algas. Proyecto Especial de GraduaciónparaIng. Agriculture EscuelaAgrícolaPanamericana, Tegucigalpa, Honduras, Page 20.

[26] Omeje, O.V., and Lambrechts, H., (2015). Effect of pawpaw (carica papaya) seed meal on the masculinization of sexually undifferentiated Mozambique tilapia (oreochromis mozambicus) Department of Animal Sciences, Faculty of Agrisciences, University of Stellenbosch, Private Bag X1, Matieland, 7602, Stellenbosch, South Africa.

[27] Ampofo-Yeboah, A., (2013). Effect of phytogenic feed additives on gonadal development in Mozambique tilapia (Doctoral dissertation, Stellenbosch: Stellenbosch University), 1-254. 